\title{
Reversing the Past. Municipal Splits in Slovakia After 1989
}

\begin{abstract}
The research on territorial reforms on the local level has so far focused on municipal amalgamations. However, less is known about municipal splits - a phenomenon that is less frequent, but that occurred in several European countries in recent decades. This paper deals with municipal splits in Slovakia after 1989, and it examines a set of factors that supported municipalities in their effort to obtain independence. The findings show that the massive wave of splits that began shortly after 1989 was primarily motivated by the aim of reversing the consequences of the amalgamation that had been conducted by the Communist regime. Hence, the question of identity was the main trigger leading to municipal splits. On the other hand, the analysis found that economic factors had only a limited role in the establishing of new municipalities in Slovakia.
\end{abstract}

Keywords

Municipalities $\bullet$ splits $•$ Slovakia $\bullet$ public administration $\bullet$ local politics

(C) University of Warsaw - Faculty of Geography and Regional Studies

Introduction

Local government represents a relevant object in the research of political science and public administration. However, when it comes to territorial reforms concerning local units, the literature has important gaps. Research to date has focused mainly on reforms initiated by central governments that have led to the mandatory amalgamation of municipalities (Gendzwiłl et al. 2020; Lima \& Neto 2018; Tavares 2018). Meanwhile, the phenomenon of municipal splits, which, contrary to amalgamation, increases the fragmentation of local units, has been somewhat underdeveloped in the existing literature.

This paper aims to fill this gap by studying the case of Slovakia and the changes in its municipal structure after 1989. With nearly three thousand municipalities, Slovakia's territorial structure is among Europe's most fragmented. This is further aggravated by the fact that nearly two thirds of Slovak municipalities have a population below a thousand people, and together these units include only 17 per cent of the state population (Sloboda 2004). In terms of territorial changes, Slovakia (until 1993 as a part of Czechoslovakia) followed an interesting trajectory. During the second half of the 20th century, the number of municipalities in the country changed considerably. First, the Communist rule between 1948 and 1989 that refused the idea of independent local government introduced a forced amalgamation of local units. As a result, the number of municipalities effectively dropped from 3,334 to 2,669 , i.e. by roughly 20 per cent. After 1989 , local government was released from its subordination to the central power, and it regained its democratic principles. In the following years, the number of municipalities grew as a result of secessions that occurred on an entirely voluntary basis; however, the number never reached the levels before the installation of the Communist regime in the mid-century.

Hence, from a scientific point of view, Slovakia represents an interesting case for several reasons. First, it is among those

\author{
Peter Spáč $\mathbb{C}$ \\ Department of Political Science, Masaryk University, \\ Brno, Czech Republic \\ e-mail: spac@fss.muni.cz \\ Received: 17 April 2020 \\ Accepted: 27 August 2020
}

countries that witnessed a nationally organised amalgamation followed by a period of numerous voluntary municipal splits. Second, these two contradictory processes took place in different political systems. While centrally planned amalgamation was conducted in a non-democratic regime, voluntary splits appeared after the re-establishment of democracy in 1989. Third and lastly, although the post-1989 establishment initially provided opportunities for municipal splits, within a single decade this attitude was reconsidered, as seen in the increasing legal barriers to the emergence of new municipalities. Slovakia thus provides a valuable case for analysis on account of the dynamic development of its territorial structure.

This paper pursues two main goals. First, it tracks the process of municipal splits in Slovakia that occurred after 1989. I analyse the development of the timeline of this process, its dynamics and its main features. This also includes a reflection on institutional rules that provided both opportunities as well as barriers for new municipalities to emerge and gain independence. The second aim concentrates on analysing the factors that lay behind the respective municipal secessions. Previous literature shows various ways this can be examined. In this paper, I apply the structure of factors set by Erlingsson (2005), adding modifications to make to better suited for Central and Eastern European countries, as provided by Swianiewicz (2021).

The structure of the paper is as follows. The first section introduces the historical background of Slovak territorial reforms. It describes the approach of Communist rule before 1989 and the forced amalgamation of municipalities in this era. The paper then highlights legal rules adopted after the re-emergence of democracy that opened the floor for municipal splits and later modifications of these rules. The following part studies the process and development of municipal splits in Slovakia after 1989, and focuses on its main features. The fourth part concentrates on 
factors that supported the municipal splits, and it explains their importance in the case of Slovakia. The final section concludes and discusses the main findings.

\section{Historical Background and Amalgamation Under Communist} Rule

Slovakia, together with the Czech Republic and France, is one of the European countries with the highest fragmentation of its municipal structure. This is not the result of a recent development but the continuation of longer historical trends. In 1921 the Slovak part of the newly emerged Czechoslovakia had around 2.3 million inhabitants who were dispersed among nearly 3,500 municipalities. The mean and median municipal population was thus well below one thousand people (Klimovský 2015).

The instalment of Communist rule in 1948 led to profound changes regarding the territorial structure and the power relations in the country. In 1949 and in 1960 new structures of regions and districts were adopted. The common principle of these reforms was to simplify the control over the state and its inhabitants by adopting a power scheme that subordinated subnational units to the centralised power of the state and by occupying newly created offices with loyal representatives of the ruling party (IIner 2010).

The reforms affected the role of the municipalities as well as their structure. In accordance with its non-democratic nature and centralist tendencies, the Communist regime abolished the idea of local self-government, resembling the provisions applied by the wartime Slovak Fascist state between 1939 and 1945. For the whole period of Communist rule, namely until 1989 , municipalities were not independent political actors led by their authorities with the direct legitimacy of local inhabitants. On the contrary, for four decades, state administration, represented by national committees, managed local issues. In other words, between 1948 and 1989, local government in Czechoslovakia operated as the extended reach of the central executive (Balík et al. 2011).

Besides degrading local government to a subordinated role, the Communist regime launched a process of amalgamation of municipalities. According to IIIner (2010), the official aim was to simplify and stratify the territorial structure. In 1950 the settlements were divided into four categories based on their roles, and in 1971 the number of categories increased to five. Such categorisation was used as a background for merging municipalities, and the aim was that the largest population centres would become the backbone of the new territorial structure. The amalgamation itself was realised in several waves and often on an involuntary basis. As a result, within a few decades, the number of municipalities dropped by more than 20 per cent. While there were more than 3,300 municipalities in 1950 , the number decreased to 2,669 by the end of 1989. The peaks of the process occurred in the 1960s and 1970 s during which time the number of municipalities fell considerably (Berčík \& Lovecký 2003).

In comparison, the decline of Slovak municipalities over the four decades of the Communist regime is rather average in purely numerical terms. As Steiner et al. (2016) show, several European countries underwent amalgamation processes between 1973 and 2013 that had an even greater impact. In four countries (Denmark, Iceland, Belgium and Greece) the number of municipalities dropped by more than a half. Of these, the Greek case is the most extreme as the number of local units decreased by nearly 95 per cent - from more than 6,000 to only 325. In the same period, the Netherlands lost more than half of its municipalities, and in Sweden and Finland, their number decreased by one third.

However, although in numerical terms these processes are comparable, they differed in nature from the Czechoslovak case. The Communist regime carried out the process in a forceful manner, without respect for local specifics and often against the will of the local population (Sloboda 2004). This is not to say that the amalgamation of municipalities in Western Europe was unequivocally accepted and led to no resistance (Erlingsson 2005; Terlouw 2017). However, the difference is that in Western Europe the amalgamations were fuelled by economic motives to increase the effectiveness of local governments. In contrast, in communist countries such as Czechoslovakia, the same process was driven by the aim to gain better control over the country and its people, and thus the motives behind it were political rather than economic. As such, the forced top-down amalgamation in Czechoslovakia led to the substantial antagonism of local units because they lost their historically rooted identities as they were absorbed into the newly integrated municipalities (IIIner 2010).

\section{Institutional and Legal Setting after 1989}

The Velvet Revolution in 1989 represented a crucial change in the development of the country, including its approach regarding the role of local government. The principle of municipalities being subordinate to the central government was removed, and the idea of local self-government was introduced (Spáč \& Sloboda 2014). Since 1990 the municipalities are no longer managed by national committees but by directly elected assemblies and mayors. Concerning territorial changes, any mandatory logic was rejected and, following the newly emerging democratic principles, entirely optional merges, as well as splits of local units, were introduced (Klimovský 2008).

The legal conditions for municipal splits were set as follows. Laws adopted in 1990 declared that splits (as well as merges) would require a local referendum. The referendum could be called either based on a decision by the local assembly or on a petition signed by at least 20 per cent of the local population. A referendum was valid under two conditions. The majority of inhabitants had to attend the vote, and the majority of those who attended had to support the idea of the split. In 1991 these thresholds were lowered and, for a successful petition, signatures by only 20 per cent of the inhabitants of the seceding part of the municipality were sufficient. The same applied to the referendum, which could be held in the seceding part of the municipality only. That meant that the approval of inhabitants of the remaining parts of the municipality was no longer required. ${ }^{1}$ Such a measure thus provided more accessible grounds for separation; however, it was based on a controversial assumption that the remaining part of the municipality would not be affected by the separation and its consequences.

The final decision on the municipal split was given to the national government. Besides the abovementioned local approval, it required a supportive statement by the district office (regional office since 1996). After 2000 the splits were allowed to occur only on the days of local elections to avoid a delay between the emergence of new municipalities and the election of their representatives. ${ }^{2}$ In general, the legal rules adopted in 1990 and slightly modified in the following years provided an easy track for municipal splits in Slovakia.

Although the data sources from the period shortly after 1989 are rather scarce, they indicate a strong positive attitude towards municipal splits on the part of the national political elite

\footnotetext{
${ }^{1}$ Although the law prescribed local referendums from 1990 onwards, some of the splits occurred before these legal rules became valid. Since there is no data on local referendums held (both valid and invalid) it remains unclear if the municipalities that emerged before the referendum was required came about due to some sort of local popular vote. Based on interviews with representatives of some of these municipalities, it was the local assemblies that approved the splits.

${ }^{2}$ In 2000 the government approved two splits and in 2001 another six splits. All these changes became valid (and thus new municipalities emerged) on the day of the local election in 2002
} 
of the time, which they perceived as an expression of the political right of the people. The reports from parliamentary sessions in 1990 and 1991 which led to the enactment of laws concerning local secessions show the focus of both the government and the parliament on the right to local self-determination especially in the case of municipalities that were subjects of the pre-1989 amalgamation process. What is more, the laws in 1990 and 1991 were appointed with an overwhelming majority in the parliament without any substantial opposing voices. Hence, at the beginning of the 1990s the national elite strongly favoured and stressed the democratic right of municipalities to gain independence (Slovak National Council, 4th Session, September 1990; Slovak National Council, 17th Session, September 1991).

This liberal approach changed substantially in 2002. As part of the preparation for entry into the EU, Slovakia implemented a substantial devolution of competences to municipalities between 2002 and 2004, followed by fiscal decentralisation in 2005 (Klimovský 2010; Klimovský 2015). At that time, the centreright Dzurinda cabinet doubted whether small municipalities would adapt to the new rules. More specifically, the government expressed its concern that small municipalities would lack the personnel and financial capacity to provide relevant services to their inhabitants. In other words, the Dzurinda cabinet generally questioned the abilities and performance of the less populated municipalities. Hence, as a reaction to the rising municipal fragmentation after 1989 (see below), the conditions required for valid splits were sharpened (Bill 4209/2001).

According to the new rules, the petition calling for a local referendum had to be signed by at least 30 per cent of the eligible inhabitants of the whole municipality. The same applied to the referendum that needed to be held in the entire municipality and not only in the seceding part. Also, a crucial population condition was adopted. The new rules required both the abandoned and the new municipalities to each have a population of at least three thousand people. Finally, splits could not be performed if the seceding part included significant investments on which the whole municipality relied. Hence, after a more relaxed attitude during the 1990s, Slovakia adopted a changed approach towards municipal splits to reduce their numbers and avoid further fragmentation of local structures (Berčík \& Lovecký 2003). Interestingly, the Czech Republic followed very similar legal developments. After a decade of a substantial increases in the number of its municipalities, from 4,120 in 1989 to 6,258 in 2000, the Czech Republic limited opportunities for new splits. More specifically, it adopted a minimum limit of 1,000 people for both new and abandoned municipalities to effectively prevent the emergence of small, new municipalities. Note that almost all Czech municipalities that emerged after 1989 had fewer than 1,000 inhabitants and half of them had a population of below 200 (Vajdová et al. 2006).

\section{Municipal Splits after 1989 in Slovakia}

After 1989 previously forced amalgamations were abandoned and, soon after, the process of voluntary fragmentation began The first case was the Ivachnová municipality, that seceded on 1 January 1990 - less than two months after the collapse of the Communist regime. Other municipalities followed shortly after that. Until 2002, after which no further changes occurred, a total of 274 new municipalities emerged. Out of these, 233 seceded from another municipality that became smaller but continued to exist. The remaining 41 local units emerged as a result of the dissolution of 19 municipalities that were divided into multiple parts and ceased to exist. Primarily, these dissolutions led to the emergence of two new municipalities but in three cases (out of 19) three new local units appeared.

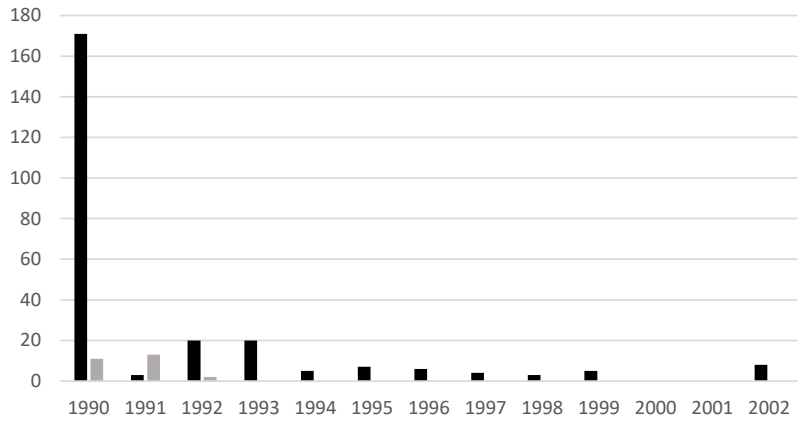

- Splits Mergers

Figure 1. Number of municipal splits and mergers after 1989 Note: For dissolutions of municipalities, only the actual surplus of local units is calculated. Due to legal regulations, the splits approved during 2000 and 2001 came into practice in 2002 on the day of the local election. Source: Berčík and Lovecký 2003

Concerning the timeframe, the distribution of splits was quite uneven. More than two thirds of municipalities that seceded after 1989 did so during the year 1990. The peak of this process occurred on the day of the first local election on 23 November 1990 when 75 new municipalities were formed. After 1990 the number of splits occurring decreased substantially and since 1994 there have been three to seven cases of secession per year. Hence, most of the fragmentation process occurred within the first months of the instalment of the democratic system and even before Slovakia emerged as an independent country in $1993 .{ }^{3}$

Alongside the splits some municipal mergers also occurred; however, these were on an entirely voluntary basis. A total of 58 municipalities joined to form 26 units, thus partly slowing the trend of the growing territorial fragmentation post-1989. In most cases, two municipalities merged into one, but in four cases three municipalities came together, and in one case the merger included four municipalities. All of these mergers took place between 1990 and 1992 and none later on (Figure 1).

The character of abandoned municipalities differed. Two thirds of the new municipalities seceded from villages, with the remaining one third from cities. The latter share might seem to be relatively high given that cities represent less than 5 per cent of all municipalities in Slovakia. ${ }^{4}$ The explanation lies in the character of the amalgamations before 1989 that aimed to enhance the centres of population. Mergers between cities and surrounding villages were one of the most typical coupling scenarios despite the relatively low share of towns in the territorial structure. As a consequence, the splits of municipalities from cities after 1989 also occurred more often as the share of cities in the country would indicate (Slavík 1994; Sloboda 2004). It is also important to note that the vast majority of splits led to the emergence of prevailingly small municipalities. More specifically, the seceded municipalities had a population mean of below 700 people. Around half of the cases were villages with less than 500 inhabitants (Table 1). On the other hand, only one fifth of new municipalities had more than a thousand people. Finally, only one out of 274 new municipalities

${ }^{3}$ This pattern was much the same in the Czech part of Czechoslovakia and later on in the Czech Republic. In the first decade after 1989, almost 2,200 new Czech municipalities emerged, out of which more than three quarters seceded in 1990. After 1994 the number of secessions dropped considerably and, from 1995, less than ten municipalities emerged each year (Vajdová et al. 2006). 
had a population above 5,000 and this was recognised as a city by the central government.

In summary, due to the massive launch of municipal splits, the year 1989 represented a turning point in the development of the number of local units in Slovakia. As Table 2 shows, the forced amalgamation decreased the number of municipalities by more than 660 units between 1950 and 1989 and thus changed the Slovak territorial structure to a large extent. In 1989 there were only 2,669 municipalities - around three quarters of the number in 1921. From 1990 the number of municipalities began to rise, until 2002 when the value stabilised at 2,891 and is still valid today. Overall, the number of local units has recovered since its significant decline during the Communist era, but it has never reached the previous levels of the 1950s or even earlier.

Factors explaining Municipal Splits in Slovakia

This section discusses the factors that lay behind the municipal splits in Slovakia. Following the model created by Erlingsson (2005) and modified by Swianiewicz (2021) two main categories have been used. First, the environmental factors that include economic and cultural issues and, second, the political factors that deal with legal regulations and the attitude of the actors involved in the process. It is important to note that the available data on the Slovak case does not allow for the role of all the enlisted factors to be evaluated.

My analysis begins with the political factors. From 1990, legal provisions set only mild conditions for municipal splits and the central government created no obstacles preventing the emergence of new municipalities. The whole process required actions on the local level only, with a supportive statement from the regional office and the approval of the cabinet. Although the national government was not obliged to follow the result of a local referendum, there is no data on any case where it disagreed with such a decision on the local level. With the upcoming devolution and fiscal decentralisation, this liberal period ended in 2002 with the enactment of more strict requirements, mainly concerning the minimum population limit.

The development of legal provisions was thus a reflection of the attitudes and behaviour of national political elites. At the beginning of the 1990s, the national government and parliament favoured the emergence of new municipalities as they underlined local communities' rights to administrative independence. After roughly a decade, the attitude of national political actors changed as they started to focus on the effectiveness and performance of local government in organisational, staffing and financial matters rather than on the right to local self-determination. This shift in the attitude of national political representatives eventually led to the enactment of legal barriers that created substantial obstacles for local splits.

In general, after these new rules came into practice in 2002, Slovakia witnessed no further municipal splits. The explanation is quite straightforward. First, it became harder to hold a valid local referendum as, from now on, not only did the seceding part have to approve the split but the inhabitants of the remaining parts of the municipality had to support the idea also. Thus, the majority of the population were given strong veto power to block any splits from their hometown.

Second, and more critical, with the adoption of the ' 3,000 $+3,000$ ' rule, the central government effectively limited possible splits to only a fraction of municipalities. Legally, after 2002, splits could occur only in municipalities with a population of at least 6,000 people. In 2001 only 111 cities (less than 4 per cent of all municipalities) fulfilled this condition in Slovakia. What is more, splits typically lead to the secession of smaller parts of a municipality (Swianiewicz 2021) and municipalities usually do not form two compact halves with the same population size which
Table 1. Population size of new municipalities

\begin{tabular}{|c|c|c|}
\hline Population & $\begin{array}{c}\text { Number of } \\
\text { municipalities }\end{array}$ & Percentage share \\
\hline Below 500 & 140 & 51.1 \\
\hline $500-999$ & 81 & 29.6 \\
\hline $1,000-1,999$ & 42 & 15.3 \\
\hline $2,000-4,999$ & 10 & 3.6 \\
\hline 5,000 and above & 1 & 0.4 \\
\hline
\end{tabular}

Source: Berčík and Lovecký, 2003

Table 2. Growth in number of municipalities since 1950

\begin{tabular}{|c|c|c|}
\hline Year & Municipalities & Difference \\
\hline 1950 & 3,334 & \\
\hline 1970 & 3,091 & -243 \\
\hline 1989 & 2,669 & -422 \\
\hline 1991 & 2,834 & +165 \\
\hline 2002 & 2,891 & +57 \\
\hline 2020 & 2,891 & 0 \\
\hline
\end{tabular}

Source: Berčík and Lovecký 2003; Statistical Office of Slovak Republic

Table 3. Municipal splits after 1990 versus legal provisions in 2002

\begin{tabular}{|c|c|c|}
\hline & $\begin{array}{c}\text { New } \\
\text { municipalities } \\
\text { with less than } \\
3,000 \text { inhabitants }\end{array}$ & $\begin{array}{c}\text { New } \\
\text { municipalities } \\
\text { with at least 3,000 } \\
\text { inhabitants }\end{array}$ \\
\hline $\begin{array}{c}\text { Abandoned } \\
\text { municipalities with } \\
\text { less than 3,000 } \\
\text { inhabitants }\end{array}$ & $134(57.5)$ & $0(0.0)$ \\
\hline $\begin{array}{c}\text { Abandoned } \\
\text { municipalities with } \\
\text { at least 3,000 } \\
\text { inhabitants }\end{array}$ & $95(40.8)$ & $4(1.7)$ \\
\hline
\end{tabular}

Source: Berčík and Lovecký 2003; author's calculation

means that the real minimum population threshold was higher than six thousand people limiting the candidates facing a potential split to an ever greater extent.

To track the true effects of the new rules, I use the splits that occurred since 1990 to assess whether they fulfil the minimum population limit of 3,000 people (Table 3 ). In this regard, only the splits leaving a functioning abandoned municipality are included $(N=233)$ while dissolutions, where the original municipality ceased to exist, are omitted. The results leave no doubt on the effectiveness of the legal conditions adopted in 2002. Almost all 
of the realised splits (229 out of 233) fail to pass the minimum population limit. In 134 cases this accounts for both the new and the abandoned municipalities. In a further 95 cases, the abandoned municipality has the required population; however, this does not apply for the seceded part. These are cases of new municipalities that split from larger towns and cities. Finally, only four splits would pass the population limit; however, it is not known whether they would also have held a valid referendum. I thus conclude that the new provisions adopted in 2002 were so strict in comparison to real developments after 1990 that they led not only to a reduction of further municipal splits but to their complete elimination. ${ }^{5}$

In terms of local political factors, the Slovak case does not allow them to be evaluated properly. First, there is no data on local referendums that led to splits or on those which were invalid. This data was not collected centrally, which poses a challenge for researchers similar to the case of the Slovak local elections (Spáč et al. 2018). Second, the role of the partisan affiliation of local actors demanding splits seems of only minor importance. As Swianiewicz (2021) states, this measure is less relevant in CEE countries due to weak role of parties in local politics. The timing of most of the splits in Slovakia supports this idea. Nearly 70 per cent of all 274 municipal splits occurred before the first local election in 1990 (including on the day of the election), and another 19 per cent happened in the next four years, that is, within the same local electoral cycle. In other words, the vast majority of municipalities seceded when new political parties lacked any local representation or when they only started to establish their grassroots structures.

I now move to economic factors. These are based on a comparison between new and abandoned municipalities which means that they do not cover the cases of dissolved municipalities. To track the scenario of 'secession of the rich' I collected data for expenditure per capita for both new and abandoned municipalities. The data is available for 224 out of 233 splits. The partial weakness of the data is that it starts in 1997, which means that for most of the splits the data is not from the year when the splits occurred but several years later.

The results indicate only a moderate ground for the 'secession of the rich' argument. Out of 224 splits, in 82 (36.6 per cent) the per capita expenditure in new municipalities exceeds the abandoned local units (Table 4). This applies to both earlier and later splits. Among earlier splits that occurred between 1990 and 1994, only 38 per cent of new municipalities had higher expenditures than the abandoned units. Among later splits (after $1995)$ this number dropped to 28 per cent. Note however that these later splits include only 25 cases, and each case thus contributes substantially to the final result. Hence, roughly two thirds of the municipalities that emerged after 1989 are worse off than the units from which they separated.

Among those with higher expenditures, the majority had a surplus of up to 50 per cent compared to the abandoned municipality. Finally, only 12 municipalities exceed their abandoned municipalities by a margin of two and more. These units constitute around 5 per cent of all cases. In summary, the numbers indicate that the 'splits of the rich' argument applies to Slovakia but only to a minority of the secessions.

Based on the literature, the effects of territorial changes are also long term (Ebinger et al. 2019) and the motivation of the 'rich parts' to secede and secure financial growth (Erlingsson 2005) may also lie in their increasing abilities to obtain surplus funding. This logic is quite straightforward. By obtaining independence,

${ }^{5}$ As noted previously, in 2000 the neighbouring Czech Republic adopted a similar regulation, setting the population limit for new and abandoned municipalities at 1,000 people. If Slovakia had used such a measure 47 out of 233 splits would have passed this threshold.
Table 4. Per capita expenditure of new and abandoned municipalities

\begin{tabular}{|c|c|c|}
\hline $\begin{array}{c}\text { Ratio new } / \\
\text { abandoned }\end{array}$ & $\begin{array}{c}\text { Number of } \\
\text { municipalities }\end{array}$ & $\begin{array}{c}\text { Percentage } \\
\text { share }\end{array}$ \\
\hline Up to 0.49 & 53 & 23.7 \\
\hline $0.50-0.75$ & 46 & 20.5 \\
\hline $0.76-1.00$ & 43 & 19.2 \\
\hline $1.01-1.24$ & 26 & 11.6 \\
\hline $1.25-1.49$ & 29 & 12.9 \\
\hline $1.50-1.99$ & 15 & 6.7 \\
\hline 2.00 and more & 12 & 5.3 \\
\hline
\end{tabular}

Source: Berčík and Lovecký 2003; author's calculation

municipalities receive better control over their financial flow, and all incoming resources are at their disposal. On the contrary, as mere parts of larger local units, they are limited in their powers, and they have to negotiate with other parts of town when local financial matters are being discussed. One such important financial channel is intergovernmental grants. Although they differ in their nature, they are a valuable source, especially in the case of infrastructure projects that the municipalities are not able to fund alone. Hence, independence might work as a way for new municipalities to secure their long-term financial interests by focusing on grant calls better suited to their needs, which would otherwise be neglected.

To test this, I construct binary logistic models that cover municipalities' access to grants from two sizeable national Slovak grant programmes managed by portfolios of the national cabinet, namely Grants for Individual Needs of Municipalities and the Environmental Fund. Note, however, that these grants represent discretionary funding only. In general, municipalities in Slovakia primarily receive mandatory funding from the state budget based on exact formulas, for example they receive a share from several taxes collected nationally. As such, the analysed funding programmes are only a surplus to this mandatory funding, and they represent only a small portion of money given to municipalities.

According to previous findings, the allocation of public resources across countries substantially supports localities ruled by representatives from the governing parties (Denemark 2000; Milligan \& Smart2005; Veiga\& Veiga 2013). For the purpose of the models, Slovak mayors are divided into three categories, namely those supported by any governing party, mayors from the opposition, and independents. I further controlled for socioeconomic features of the municipalities, namely the population size, the share of ethnic Hungarians, and unemployment. Finally, to map the effects of splits, I use two dummy variables, one for new and the other for abandoned municipalities. The data cover a period between 2004 and $2017^{6}$ and the models include time fixed effects.

The results (Table 5) confirm that grants are primarily distributed among partisan lines. Municipalities with mayors from governing parties substantially benefit from the allocation primarily at the expense of localities led by mayors from the opposition.

${ }^{6}$ The time span is set based on the conditions of the analysed grant programmes. The programme of Grants for Individual Needs of Municipalities started in 2004, and the Environmental Fund emerged in 2005. For this paper, grant schemes from earlier periods would be more suitable as most municipal splits occurred in the first half of the 1990s; however, no such data exists. 
More importantly, the results indicate that separation after 1989 did not provide the new municipalities with any advantage in terms of obtaining discretionary grants at the national level. In the programme for individual needs of municipalities, new municipalities had slightly higher odds of receiving such funding compared to abandoned municipalities. On the other hand, in the distribution of the Environmental Fund, the reverse is true. Note, however, that the found effects are not substantial and in terms of predicted probabilities the new and abandoned municipalities differ with a margin of three to four percentage points in their probabilities of obtaining the respective grants. Overall, the findings show that new municipalities in Slovakia were not more successful or effective in obtaining public grants compared to the municipalities they abandoned. Given the time span of the analysed grant programmes, it cannot be excluded that splitting from a larger urban area during the 1990s increased the likelihood of new municipalities obtaining intergovernmental grants but, in the long-term, such a scenario did not occur. In other words, if municipalities separated after 1989 to obtain better grounds for receiving more surplus funding at the national level, results show that such ambitions remained unfulfilled.

Given that the period between 2004 and 2017 witnessed five different governments, I constructed models for each of the cabinets to check the robustness of the results. In nine out of these ten models, no meaningful effects for both new and abandoned municipalities are found. The only exception is the model for the Environmental Fund and the first government led by Robert Fico (in office until 2010) in which the new municipalities had a lower chance of obtaining the subsidies; however, the effect is not substantial. This robustness check thus confirms that access to discretionary funding does not differ among new and abandoned municipalities. $^{7}$

The other economic factor concerns one municipal part having the sense of being exploited or colonised by the rest of the municipality, thus enhancing its will to separate. This sense primarily stems from a subjective attitude that funds are used on policies that do not follow the preferences and interests of the respective part of the municipality. Such centrifugal tendencies typically grow when the exploited part has a peripheral location and when it is substantially smaller compared to the remaining municipality, which limits its political representation inside the municipality (Swianiewicz 2021).

Based on data from 233 splits, these supporting conditions were largely present in the Slovak case. First, new municipalities in Slovakia are indeed considerably smaller than the units they abandon. The mean ratio between the population of abandoned and new units is above 19. This means that on average, splits cause roughly a 5 per cent decrease in the number of inhabitants of the abandoned municipalities. This population ratio is considerably higher for secessions from cities (Figure 2). For instance, in 20 cases, the population of new municipalities was more than 50 times smaller than in the abandoned city. Second, before secession, new municipalities were typically located at the periphery of larger urban areas. This was mostly a typical product of amalgamations before 1989 that concentrated on increasing the size of large cities by consuming the surrounding settlements that were of a rural, and thus utterly different, character (Sloboda 2004). However, even though these conditions - the small size compared to the remaining municipality and the peripheral location - can be identified in Slovakia, there is no data, such as that on the intra-

${ }^{7}$ also calculated models that included a further control variable covering municipal fiscal health, i.e. a composite index based on several economic indicators such as debts, receivables and account balance (INEKO Financial Health). This index has been measured since 2007, which means that I only calculated models, including this variable, since 2007 . Inclusion of this variable did not alter the obtained results.
Table 5. Access to grants for individual needs of municipalities and the environmental fund

\begin{tabular}{|c|c|c|c|c|}
\hline & \multicolumn{2}{|c|}{$\begin{array}{c}\text { Grants for } \\
\text { Individual Needs of } \\
\text { Municipalities }\end{array}$} & \multicolumn{2}{|c|}{$\begin{array}{c}\text { Environmental } \\
\text { Fund }\end{array}$} \\
\hline & B & Std. E & B & Std. E \\
\hline $\begin{array}{c}\text { Mayor from } \\
\text { governing party }\end{array}$ & 1.48 & 0.05 & 0.87 & 0.05 \\
\hline $\begin{array}{c}\text { Independent } \\
\text { mayor }\end{array}$ & 0.39 & 0.05 & 0.38 & 0.05 \\
\hline $\begin{array}{c}\text { Population (log) } \\
\text { Unemployment }\end{array}$ & -0.08 & 0.02 & 0.07 & 0.02 \\
\hline $\begin{array}{c}\text { Share of } \\
\text { Hungarians }\end{array}$ & -0.01 & 0.00 & 0.01 & 0.00 \\
\hline New municipality & -0.03 & 0.06 & -0.17 & 0.08 \\
\hline $\begin{array}{c}\text { Abandoned } \\
\text { municipality }\end{array}$ & -0.21 & 0.08 & -0.08 & 0.08 \\
\hline \begin{tabular}{c} 
(Intercept) \\
\hline N
\end{tabular} & -1.39 & 0.13 & -0.57 & 0.16 \\
\hline AlC & 20,567 & \multicolumn{2}{|c|}{14,532} \\
\hline \multicolumn{2}{|c|}{21,725} & \multicolumn{2}{|c|}{17,058} \\
\hline
\end{tabular}

Note: Binary logistic regression models are calculated. Dependent variable is binary, with value one for municipalities that received subsidies, and value zero otherwise. Source: author's calculation

municipal distribution of funds or surveys of inhabitants, that provides evidence of the subjective feelings of being exploited. Due to the lack of such data, whether such factors played a role in the process of voluntary splits after 1989 cannot be evaluated.

The final category of factors of municipal splits relates to cultural issues. In this regard, Erlingsson (2005) stresses the argument of inappropriately drawn borders, which points to differences between artificial divisions on the map that result from decisions at the central level and natural boundaries that arose from historical developments. Swianiewicz (2021) stresses the role of the previous identity which applies to municipalities that became part of a top-down process of amalgamation realised without their consent. I use the latter argument, which focuses on the 'social memory' of people who remember their municipality being an independent unit with its own name, history and identity. As such, municipal splits should arise as a result of a stronger identification with the status quo before the amalgamation took place. In the case of Slovakia, the occurrence of splits, their time development and further historical facts strongly suggest that this factor was the dominant engine leading to the vast majority of municipal separations after 1989.

First, it is essential to note that more than 90 per cent of post-1989 splits account for municipalities that were the subject of amalgamations during the Communist rule (Berčik \& Lovecký 2003). Thus, an overwhelming majority of new municipalities were merged into larger units between 1948 and 1989. Such a high share indicates that municipal splits were primarily conducted to correct the consequences of amalgamation by the nondemocratic regime. 
MISCELLANEA GEOGRAPHICA - REGIONAL STUDIES ON DEVELOPMENT

Vol. 25 • No. 1 - 2021 • pp. 28-36 • ISSN: 2084-6118 • DOI: 10.2478/mgrsd-2020-0045

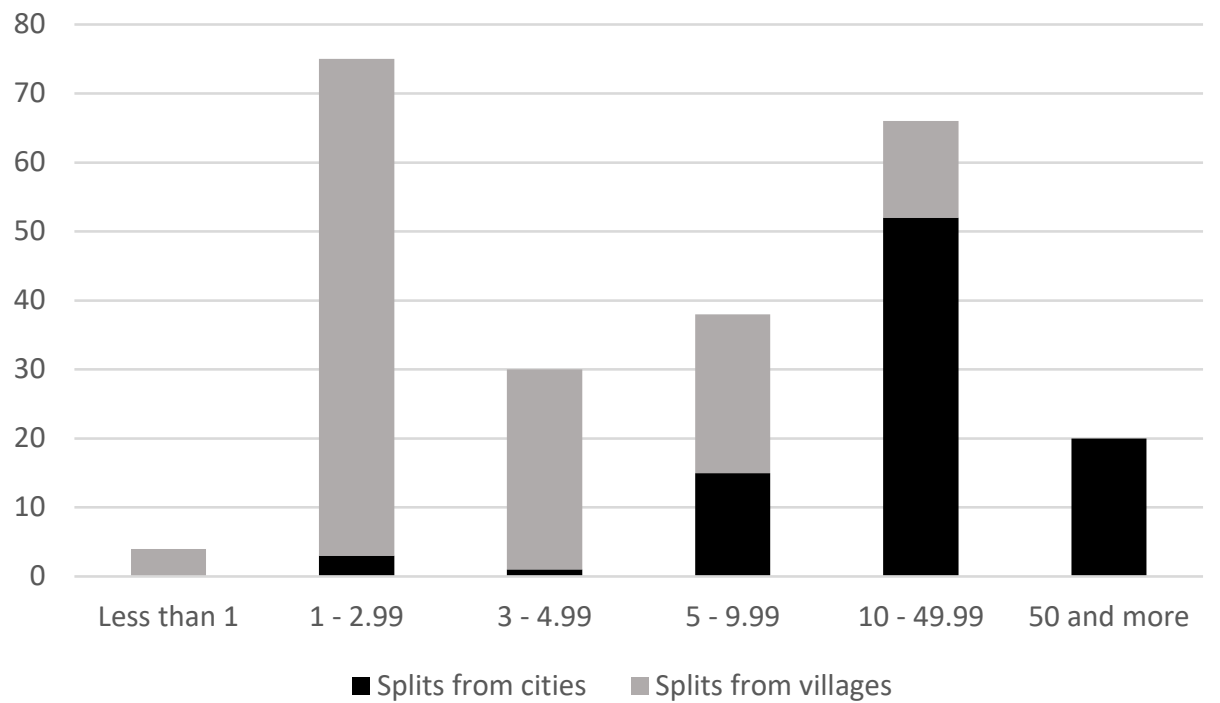

Figure 2. Population ratio of new and abandoned municipalities Source: Berčík and Lovecký 2003; author's calculation

Second, the inclusion of a further historical dimension only supports this argument. Almost all municipalities that separated after 1989 have historical roots dating back many centuries. Only in fewer than ten cases were the municipalities founded during the 19th or 20th centuries. On the contrary, more than 250 of the new municipalities have a history of at least 500 years. What is more, historical documents show that even in medieval times, municipalities had at least some sort of independent functioning local government (Berčík \& Lovecký 2003). This means that nearly all the analysed municipalities share a formidable memory of their independent development or what Swianiewicz (2021) mentions as 'days of glory deep in the past ages'.

The importance of such an identity issue is evident when the pre-1989 amalgamation period is taken into account. Municipalities that were merged during the 1960s showed a rather low willingness to reobtain their independence, as only 26.7 per cent of them conducted a split after 1989. In the case of municipalities that were subject to amalgamations in the 1970s, this value rises to 41.5 per cent. Finally of the 56 municipalities that were merged in the 1980 s, nearly 90 per cent (50 cases) separated after 1989 (Berčík \& Lovecký 2003). These findings show that if the amalgamation occurred more recently, the memories of own independence and identity remained strong and led to a split after the non-democratic regime collapsed. ${ }^{8}$ On the contrary, if the amalgamation happened earlier, such as the one in the 1960 s, the local population either accepted such a scenario after several decades or the collective memory of a previous identity diminished and was no longer a factor.

Third and finally, the concentration of most separations in 1990 - shortly after the emergence of the democratic system - shows that the splits were part of a more general process of dealing with the recent past. The pre-1989 amalgamations aimed to gain control over the country (IIIner 2010) - this was one of the various mechanisms of the Communist regime and was based

${ }^{8}$ For instance, the history of the village of Hronsek dates back to the 13th century. In 1979 it was merged with the city of Banská Bystrica from which it seceded and regained independence in January 1993. Similarly, the first documents on the village of Ivachnová date back to the late 13th century. In July 1976 it was merged with the town of Liptovská Teplá. Ivachnová regained its independence in 1990 (Berčík \& Lovecký 2003). Such examples show that the periods between amalgamation and secession were only short episodes in the existence of the villages. on force, as was the unchallenged role of the ruling party and the absence of free elections. The democratic euphoria and strong anti-communist sentiments at the beginning of the 1990s thus provided a suitable environment to reverse the pre-1989 regulations. In summary, the fact that most splits occurred within months after the collapse of the Communist regime, indicates that they were primarily motivated by substantial discontent with the previous amalgamation and the strong will to alter its consequences. Hence, the cultural and identity factors turned out to be the most important issues that led to municipal splits in Slovakia. ${ }^{9}$

\section{Conclusions}

The phenomenon of municipal splits has been mostly omitted in the research on territorial changes and reforms on the local level. Unlike amalgamations, splits are based on voluntary bottom-up decisions, and they occur as individual acts rather than systematic and general policies of national governments. Despite this, splits on the local level are a relevant issue as, alongside amalgamations, their analysis completes our knowledge on territorial changes and their consequences on the local level (Swianiewicz 2021).

This paper analysed the municipal splits in Slovakia after 1989. After the collapse of the Communist regime that enforced amalgamations on the local level, the country witnessed a massive rise in the number of municipalities. Most of the splits took place shortly after the main political changes, with the peak occurring in 1990. In the following decade, the number of municipalities gradually, albeit slowly, increased, and this trend stopped after new regulations were applied in 2002, leaving the number of municipalities at 2,891, a figure which remains valid. Similar to the Czech case, Slovakia also followed a trajectory starting with mild conditions that favoured splits. This was supported by the attitudes of national political elites who, at the beginning of the 1990s, stressed the right to self-determination

II is important to note, however, that the social memory of inhabitants of seceded municipalities was not measured directly. For this purpose, an optimal data source would be a survey conducted among residents of these towns with questions oriented towards the importance of previous local identity, opinions on the amalgamation and later secession. However, no such data exists and, given that most splits occurred at the beginning of the 1990s, it hardly seems possible at present to carry out such a survey. 
on the local level. Such an approach was, however, reconsidered a decade later, when the elites started to focus instead on the actual performance of the local governments. This resulted in a substantial reduction or nearly an elimination of opportunities for municipalities to separate.

The main finding of this paper is that in the case of Slovakia, municipal splits were primarily a reaction to pre1989 amalgamations and they aimed to correct the wrongful mergers of the past. An overwhelming majority of municipalities that separated after 1989 were subject to amalgamation under Communist rule, which had been conducted with little respect of the needs of local settlements and their population. After the instalment of the democratic system, these units seized the first opportunity to regain their independence, and most of them did so almost immediately. I thus conclude that, in the case of Slovakia, municipal splits were primarily motivated by the will to regain the independence that the respective municipalities had lost in the pre-1989 amalgamation process. Apart from that, some support was also found for the theory that they were motivated by economic factors and the 'secession of the rich' argument; however, the role of these factors seems to be modest in Slovakia and only applies to a small number of splits.

An important finding concerns the question of identity. Although the amalgamation under Communist rule led to the emergence of less numerous units with a higher population, the previous local identities did not disappear. On the other hand, the municipal splits after 1989 indicate that these memories of former local identity eroded over time. The consequence of this can be seen in the share of splits among municipalities that were amalgamated in different decades of the 20th century. While almost all municipalities that faced amalgamation in the final decade of the Communist regime regained their independence after 1989 , only one out of four of those that were merged in the 1960s made the same decision. This finding has a more general theoretical implication, and it suggests that the longer the length of time that passes after amalgamation, the more previous identities tend to weaken, even when the merge did not happen with the consent of the local populations. The case of municipal splits in Slovakia thus provides significant findings, enriching the analytical debate on territorial reforms and their consequences.

\section{Acknowledgments}

This article was supported by Czech Science Foundation (GA18-16928S).

\section{ORCID}

Peter Spáč (1D) https://orcid.org/0000-0003-4395-689X

\section{References}

Balík, S, Hloušek, V, Holzer, J \& Šedo, J 2011, Politický vývoj českých zemí 1848-1989 [Political Development of Czech Lands 1848-1989], MPÚ, Brno.

Berčík, P \& Lovecký, P 2003, Územné zmeny obcí v SR od roku 1990 [Territorial Changes of Municipalities in Slovakia after 1990]. Available from <https://www.minv. sk/?uzemne-zmeny-obci-v-slovenskej-republike-od-roku1990\&subor $=21833>$. [17 July 2020].

Bill 4209/2001. Available from <https://www.nrsr.sk/web/ Dynamic/DocumentPreview.aspx?DoclD=407222>. [17 July 2020].

Denemark, D 2000, 'Partisan Pork Barrel in Parliamentary Systems: Australian constituency-level grants', The Journal of Politics, vol. 62, no. 3, pp. 896-915.

Ebinger, F, Kuhlmann, S \& Bogumil, J 2019, 'Territorial reforms in Europe: effects on administrative performance and democratic participation', Local Government Studies, vol. 45 , no. 1 , pp. $1-23$.

Erlingsson, GÓ 2005, 'Modelling secessions from municipalities', Scandinavian Political Studies, vol. 28, no. 2, pp. 141-159.

Gendzwiłt, A, Kurniewicz, A \& Swianiewicz, P 2020, 'The impact of municipal territorial reforms on economic performance of local governments. Systematic review of quasi-experimental studies', Space and Polity.

Hospodárenie obcí 2020, INEKO Financial Health. Available from: <http://www.hospodarenieobci.sk>. [17 July 2020].

Illner, M 2010, 'Top-down or bottom-up? Coping with territorial fragmentation in the Czech Republic' in Territorial Choice, eds H Baldersheim \& LE Rose, The Politics of Boundaries and Borders, Palgrave Macmillan, New York.

Klimovský, D 2008, 'Politics and its impact on the reform processes: the case of public administration reform in Slovakia (1989-2006)' in Space and Historical Time as Dimensions of Social Change, ed. J Musil, Matfyzpress, Prague, pp. 45-64.

Klimovský, D 2010, 'Public administration reform in Slovakia: 20 years of experience with different institutional settings at the local and regional levels', Analytical, vol. 3, no. 1, pp. 28-55.
Klimovský, D 2015, 'Slovakia as decentralization champion: Reality or myth?', Regions Magazine, vol. 298, no. 1, pp. 14-16.

Lima, RCA \& Neto, RMS 2018, 'Secession of municipalities and economies of scale: Evidence from Brazil', Journal of Regional Science, vol. 58, no. 1, pp. 159-180.

Milligan, K \& Smart, M 2005, 'Regional grants as Pork Barrel Politics', CESifo Working Paper No. 1453.

Slavík, V 1994, 'Proces integrácie a dezintegrácie obcí v SR ako súčast' lokálnej politiky' ['Process of integration and disintegration of municipalities in Slovakia as a part of local politics'] in Rozvoj vidieka [Development of the countryside] (conference proceedings), VSP, Nitra.

Sloboda, D 2004, 'Charakter sídelnej štruktúry Slovenska ako predpoklad pre komunálnu reformu' ['Character of settlement structure of Slovakia as a precondition for a communal reform']. Available from: <http://konzervativizmus.sk/wpcontent/upload/prezentacie/Sloboda_komreforma.pdf>. [17 July 2020].

Slovak National Council, $4^{\text {th }}$ Session, September 1990. Available from: <https://www.nrsr.sk/dl/Browser/ Document?documentld=74795>. [17 July 2020].

Slovak National Council, 17 ${ }^{\text {th }}$ Session, September 1991. Available from: <https://www.nrsr.sk/dl/Browser/ Document?documentld=4311>. [17 July 2020].

Spáč, P \& Sloboda, D 2014, Municipalizácia, volebný systém a možnosti participácie $v$ miestnej samospráve na Slovensku [Municipalization, electoral system and possibilities of participation in local government in Slovakia], KVPC, Piešt'any.

Spáč, P, Voda, P \& Zagrapan, J 2018, 'Does the freedom of information law increase transparency at the local level? Evidence from a field experiment', Government Information Quarterly, vol. 35, no. 3, pp. 408-417.

Steiner, R, Kaiser, C \& Eythórsson, GT 2016, 'A comparative analysis of amalgamation reforms in selected European countries' in Local Public Sector Reforms in Times of Crisis, eds S Kuhlmann G Bouckaert, Palgrave Macmillan, New York. pp. 23-42. 
Swianiewicz, P 2021, 'From post-communist democratic laissezfaire to prevention of territorial fragmentation: tightening the rules of municipal splits in Central and Eastern Europe after 1990', Miscellanea Geographica - Regional Studies on Development, vol. 25, no. 1, pp. 5-17.

Tavares, AF 2018, 'Municipal amalgamations and their effects: a literature review', Miscellanea Geographica, vol. 22, no. 1, pp. 5-15.

Teorluw, K 2017, Local identities and politics. Negotiating the old and the new, Routledge, Abingdon.

Vajdová, Z, Čermák, D \& IIIner, M 2006, Autonomie a spolupráce: důsledky ustavení obecního zrrízení v roce 1990 [Autonomy and Cooperation: Consequences of Founding of Municipal Establishment in 1990], Sociologický ústav AV ČR, Praha.

Veiga, LG \& Veiga, FJ 2013, 'Intergovernmental fiscal transfers as pork barrel', Public Choice, vol. 155, no. 3/4, pp. 335353. 